\title{
A Case of Encephalopathy Caused by Ceftriaxone Resistant Shigella flexneri
}

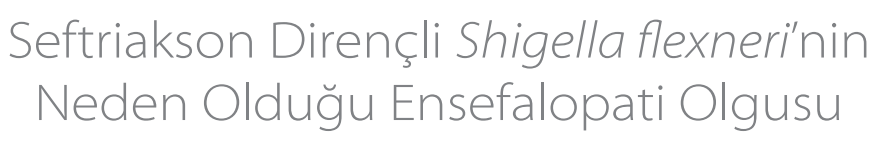

\author{
Mehtap Altuntaş', Sevgi Yaşar Durmuş², Nur Öz², H. Özlem Altay Akışoğlu³, Ayşe Kaman², \\ Türkan Aydın Teke², Gönül Tanır² \\ ${ }^{1}$ Clinic of Pediatrics, Dr. Sami Ulus Obstetrics and Gynecology, Child Health and Diseases Hospital, Ankara, Turkey \\ ${ }^{2}$ Clinic of Pediatric Infectious Diseases, Dr. Sami Ulus Obstetrics and Gynecology, Child Health and Diseases Hospital, Ankara, Turkey \\ ${ }^{3}$ Division of Microbiology, Dr. Sami Ulus Obstetrics and Gynecology, Child Health and Diseases Hospital, Ankara, Turkey
}

Cite this article as: Altuntaş M, Yaşar Durmuş S, Öz N, Altay Akışoğlu HÖ, Kaman A, Aydın Teke T, et al. A case of encephalopathy caused by ceftriaxone resistant Shigella flexneri. J Pediatr Inf 2018;12(3):e118-e120

\section{Abstract}

Shigella is a common causative agent of gastroenteritis especially in developing countries. Species that cause Shgellosis, have diversity between countries. Shigella sonnei is the first, Shigella flexneri is the second most common isolated species in our country. Because of their genetical predisposition, they can quickly develop resistance to antibiotics therefore antibiotic susceptibility of Shigella species are variable. Antibiotic resistance rate in S. flexneri infections is higher than other Shigella species. Herein we report a case, who presented with altered conscious. In the follow up he had diarrhea and ceftriaxone resistant S. flexneri was yielded from his stool. We wanted to emphasize that shigellosis should be considered in patients that presented with altered conscious and the diarrhea may occur after neurological findings.

Keywords: Ceftriaxone resistance, encephalopathy, Shigella flexneri

\section{Introduction}

Shigella species are gram-negative bacteria infecting the human gastrointestinal tract, resulting in schigellosis that can affect systems other than the gastrointestinal tract (1). Shigellosis affects 164 million people annually around the world, resulting in the death of 1.1 million people (2). Shigella spe-
Öz

Shigella özellikle gelişmekte olan ülkerlerde yaygın bir gastroenterit etkenidir. Şigelloza yol açan türler ülkeler arasında farklılık göstermektedir. Ülkemizde Shigella sonnei birinci, Shigella flexneri ikinci sıklıkta izole edilen türlerdir. Genetik yatkınlıkları nedeniyle antibiyotiklere hızla direnç geliştirebilirler bu nedenle Shigella türlerinin antibiyotik duyarlılıkları değişkendir. S. flexneri'de antibiyotik direnci diğer Shigella türlerine göre daha yüksektir. Burada bilinç değişikliği ile başvuran, takibinde ishali gelişen ve gaita kültüründe seftriakson dirençli S. flexneri izole edilen bir olgu sunduk. Bilinç değişikliği ile başvuran hastalarda şigellozun düşünülmesi gerektiğini ve ishalin nörolojik bulgulardan sonra ortaya çıkabileceğini vurgulamak istedik.

Anahtar Terimler: Ensefalopati, seftriakson direnci, Shigella flexneri

cies can be classified into four categories based on their serological characteristics and biochemical reactions: Group A (Shigella dysenteria), Group B (Shigella flexneri), Group C (Shigella boydii) and Group D (Shigella sonnei). S. sonnei is the most common species in developed countries, whereas $S$. flexneri is more common in developing countries, although outbreaks are often caused by S. dysenteria. In Turkey, S. sonnei and S. flex- 
neri are the first and second most commonly isolated species, respectively $(1,2)$. Typical clinical findings in children include acute onset fever, weakness, abdominal cramps, abundant and watery or bloody diarrhea, painful defecation and toxic appearance, while the most common extraintestinal findings include generalized convulsions, headache, lethargy, confusion and neck stiffness; and neurological findings include hallucinations that may precede diarrhea $(2,3)$. The present manuscript reports on a nine-year-old male patient who presented with encephalopathy in whom a stool culture revealed ceftriaxone-resistant $S$. flexneri, highlighting that neurological findings may precede diarrhea, and that the agent may be resistant to ceftriaxone.

\section{Case Report}

A nine-year-old previously healthy male patient was admitted to our hospital with a three-day fever, with vomiting followed by hallucinations. The patient had attended an another hospital with the same complaints, suffering from hallucinations such as seeing nonexistent objects next to his mother after having been prescribed amoxicilline-clavulanic acid, ibuprofen and methoclopramide. Later, the patient was hospitalized at the same facility, and with a prediagnoses of drug side effect and encephalitis, a therapy of ceftriaxone, vancomycin, acyclovir and metronidazole was initiated. The patient was then referred to our facility with persistent fever and hallucinations. Upon physical examination, the patient's general condition was found to be moderate and lethargic. His body temperature was $37.3^{\circ} \mathrm{C}$, pulse rate was $124 \mathrm{bpm}$, blood pressure was $120 / 70 \mathrm{mmHg}$ and respiratory rate was 24 per minute, while all other systems were normal. In laboratory tests, hemoglobin was $13.9 \mathrm{~g} / \mathrm{dL}$, white blood cell count was $5.9 \times 10^{3} / \mu \mathrm{L}(80 \%$ polymorphonuclear leukocytes, $12 \%$ lymphocyte, $8 \%$ monocyte), platelet count $190 \times 10^{3} / \mu \mathrm{L}$, and the erythrocyte sedimentation rate was $60 \mathrm{~mm} / \mathrm{hr}$, C-reactive protein (CRP) was $406 \mathrm{mg} / \mathrm{L}$ (normal ranges $0-4 \mathrm{mg} / \mathrm{L}$ ). Serum sodium was $130 \mathrm{meq} / \mathrm{L}$, phosphor was $3.3 \mathrm{mg} / \mathrm{dL}$, and other serum electrolytes, kidney function tests, liver enzymes and serum bilirubin levels were within normal ranges. An examination of the cerebrospinal fluid (CSF) showed no cells, protein was $33.4 \mathrm{mg} / \mathrm{dL}$, glucose was $54 \mathrm{mg} / \mathrm{dL}$ and the concurrent blood glucose was $100 \mathrm{mg} / \mathrm{dL}$. Diarrhea started in the follow-up period, although a direct microscopic examination of the stool was revealed no leukocytes. Maintenance fluid therapy adjusted to age and empirical parenteral ceftriaxone were initiated. On the second day of hospitalization, the patient passed an abundant amount of stool containing fresh blood and clots accompanied by marked tenesmus. A stool culture in xylose lysine deoxycholate (XLD) and a Müller Hinton media revealed $S$. flexneri type $2 b$ that was resistant to ampicillin, trimethoprim-sulfamethoxazole (TMP-SMX) and ceftriaxone, and so the therapy was switched to ciprofloxacin. No bacterial growth was identified in the CSF and blood cultures, and the patient's general condition improved in the follow-up period. His lethargy recovered, the bloody diarrhea ceased and the patient was discharged with instructions to complete the ten days of therapy.

\section{Discussion}

Shigella is the most commonly isolated pathogen in the stools of children with bloody diarrhea in developing countries. Among the Shigella species, S. flexneri is the most common cause of infection in developing countries, whereas $S$. sonnei is the most common agent in industrialized countries. An inoculum of 10-100 bacteria is sufficient to produce the disease. The symptoms following an incubation period ranging from 12 hours to two days include fever, lack of appetite, nausea, vomiting, cramping abdominal pain and diarrhea $(1,4,5)$. The complications of Shigellosis can be classified as intestinal and systemic, with intestinal complications including dehydration, intestinal perforation and toxic megacolon, and extraintestinal complications including septicemia, hyponatremia, hypoglycemia, seizures, encephalopathy, hemolytic uremic syndrome, pneumonia, changes in coagulation parameters and malnutrition $(1,6)$. Hyponatremia can occur in association with all Shigella species, although this is caused by inappropriate ADH syndrome rather than a loss of sodium in the stool (6). Patients can develop encephalopathy, and this can manifest in a variety of ways, ranging from altered consciousness to coma, and brain edema caused by hypoglycemia, electrolyte disturbances and hyponatremia have been implicated in its etiology $(1,6)$. The reported case is consistent with shigellosis, considering the fever, altered consciousness and hallucinations followed by diarrhea. The patient had a drug history (methoclopramide) affecting the central nervous system, although studies in literature have reported that side effects related to methoclopramide often occur with repeated use, and mostly involve the extrapyramidal system (7). Although seizures are the most common neurological complication of shigellosis, there have also been cases reported with hallucinations that are of benign character, and that recede as the patient recovers from the disease (8). The present case had used a single dose of drug with neurological side effects, and so the altered consciousness and hallucinations were considered to be related to shigellosis as the hallucinations sustained after the cessation of the suspected drug and S. flexneri was reproduced in the stool culture.

The main approach to the treatment of diarrhea caused by Shigella species is supportive fluid and electrolyte replacement. The initiation of appropriate antibiotics reduces the risk 
of complications developing, shortens the duration of the febrile period and diarrhea, and reduces the excretion of the pathogen in the stool (3). For this purpose, empirical ceftriaxone therapy was initiated with a pre-diagnosis of invasive gastroenteritis, although the therapy was switched to ciprofloxacin after it was understood that the infection had been caused by a ceftriaxone-resistant species. The diarrhea lasted for six days in the follow-up period, and no complications occurred.

Shigella species can develop an antibiotic resistance through such transposable DNA segments as plasmid, transposon and integron, and so the antibiotic susceptibility pattern of Shigella species is variable. Empirical antibiotherapy should be initiated considering the local antimicrobial resistant profile (9). According to US National Antimicrobial Surveillance system data, 41 percent of Shigella species are resistant to ampicillin, 48 percent are resistant to TMP-SMX and 2 percent are resistant against ciprofloxacin, whereas ceftriaxone resistance was reported to be less than 1 percent in 2010 (10). There is an increasing resistance to aminoglycosides and quinolones in Asia and Africa, whereas resistance to ceftriaxone was reported to be less than 14.2 percent (11). In a study conducted in Turkey in 2002, resistance to TMP-SMX was reported to be 90.4 percent, whereas sensitivity to ampicillin was 86.4 percent, sensitivity to cefotaxime was 98 percent and sensitivity to ciprofloxacin was 100 percent (4). No resistance to gentamicin, ceftriaxone, nalidixic acid, imipenem or ciprofloxacin was reported in a 2008 study, whereas in a 2012 study of 60 Shigella isolates, no resistance to ciprofloxacin and gentamicin was reported, while the rate of resistance against cefotaxime was 22.2 percent $(9,12)$. This finding suggests an emerging resistance to cefotaxime and ceftriaxone in Turkey. The $S$. flexneri type $2 \mathrm{~b}$ strain isolated from our case was resistant to ampicillin, TMP-SMX and ceftriaxone, and so the empirical use of ceftriaxone had no effect, and therapy was switched to ciprofloxacin.

\section{Conclusion}

The case reported in this manuscript indicates that Shigella infection must be considered in differential diagnoses of patients presenting with diarrhea and encephalopathy, and that neurological symptoms may precede diarrhea. Due to the variable resistance profile of the Shigella species against antimicrobial therapy, having the knowledge of the local antimi- crobial resistance profile through surveillance studies would increase the success of treatments, and would be beneficial in the selection of appropriate antibiotics.

Informed Consent: Informed consent was obtained from the patient and his parents.

Peer-review: Externally peer-reviewed.

Author Contributions: Concept - SYD, NÖ, GT; Design - AK, TAT, MA; Supervision - GT, TAT; Collection and/or Processing - SYD, MA, AK Analyse - HÖAA, NÖ; Literature Review - SYD, MA, HÖAA; Writing MA, SYD, NÖ; Critical Review - TAT, NÖ; Patient Monitoring - All authors.

Conflict of Interest: The authors have not reported a conflict of interest.

Financial Disclosure: There is no financial support in this study.

\section{References}

1. Ashkenazi S. Shigella infections in children: New insights. Semin Pediatr Infect Dis 2004;15:246-52.

2. Karacan C, Tavil B, Topal Y, Zorlu P, Tayman C. Evaluation of shigellosis in a Turkish children's hospital. Pediatr Int 2007;49:589-92.

3. Ashkenazi S, Cleary TG. Shigella species. In: Long SS, Pickering LK, Prober CG (eds). Principles and Practise of Pediatric Infectious Diseases. 3rd ed. Philedelphia: Churcill Livingstone, 2009;817-20.

4. Ozmert EN, Ince OT, Orun E, Yalcın S, Yurdakok K, Gur D. Clinical characteristics and antibiotic resistance of Shigella gastroenteritis in Ankara, Turkey between 2003 and 2009 and comparasion with previous reports. Int J Infect Dis 2011;15:e849-53.

5. DuPont HL. Bacillary dysentery: Shigella and enteroinvazive Escherichia coli. In: Mandell Douglas and Bennett's Principles and Practise of Infectious Diseases, Updated Edition 226, 2569-2574.

6. Bennish ML. Potentially lethal complications of Shigellosis. Rev Infect Dis 1991;13 (Suppl 4):S319-24.

7. Lau Moon Lin M, Robinson PD, Flank J, Sung L, Dupuis LL. The Safety of metoclopramide in children: a systematic review and meta-analysis. Drug Saf 2016;39:675-87.

8. Diercks $D B$, Friedland $L R$, Ernst $A A$. Hallucinations as the initial presentation of shigellosis. Pediatr Emerg Care 2000;16:99-101.

9. Saran B, Erdem B, Tekeli FA, Sahin F, Aysev AD. Characterization of Shigella strains isolated in ankara, Turkey by antimicrobial resistance models, plasmid profile analysis and pulsed-field gel electrophoresis. Mikrobiyol Bul 2013;47:35-48.

10. Holmes LC. Shigella. Pediatr Rev 2014;35:261-2.

11. Gu B, Zhou M, Ke X, Pan S, Cao Y, Huang Y, et al. Comparison of resistance to third-generation cephalosporins in Shigella between Europe-America and Asia-Africa from 1998 to 2012. Epidemiol Infect 2015;143:2687-99.

12. Kurugöl Z, Devrim i. Gastrointestinal enfeksiyonlar. J Pediatr Inf 2014;8:71-81. 